\title{
Perception of Harmful Traditional Practices Among Women of Childbearing Age in Oru West Local Government Area, Imo State
}

\author{
Olaoluwa Samson Agbaje ", Benedicta Ndidi Agu, Kenechukwu Chinenye Osakwe \\ Department of Public Health, Faculty of Health Sciences, Madonna University Elele, Rivers State, Nigeria \\ Email address: \\ agbajesam@yahoo.com (O.S.Agbaje), benemdi@yahoo.com (B. N. Agu), kosakwe@yahoo.com (K. C. Osakwe) \\ To cite this article: \\ Olaoluwa Samson Agbaje, Benedicta Ndidi Agu, Kenechukwu Chinenye Osakwe. Perception of Harmful Traditional Practices Among \\ Women of Childbearing Age in Oru West Local Government Area, Imo State. Science Journal of Public Health. \\ Vol. 3, No. 2, 2015, pp. 150-160. doi: 10.11648/j.sjph.20150302.11
}

\begin{abstract}
Harmful traditional practices pose severe health risks to girls and women. Women's perception of harmful traditional practices may assist in their eradication or perpetuate them. There is paucity of research on perception of harmful traditional practices among women in Oru West LGA, Imo State. A cross-sectional survey research design was adopted for the study. The study population comprised 31,838 registered women of child bearing age who registered for ANCs from January, 2014 to September, 2014 in Oru West LGA, Imo State at the time of study. A sample of 384 women of childbearing age was used for the study. The multistage sampling procedure was adopted to select the sample. The instrument for data collection was a structured Questionnaire on Perception of Harmful Traditional Practices among Women. The questionnaire was validated by three experts. Reliability co-efficient of the instrument was 0.81 . Data analysis was performed using Statistical Package for Social Sciences (version 20). The results showed that 49.3 per cent of women perceived identified traditional practices as harmful to women. Age of women had influence on perceived harmful traditional practices while no significant difference was found in the perception of harmful traditional practices based on women's level of education. This study envisages that harmful traditional practices are prevalent in different cultural backgrounds in Nigeria with attendant health risks for girls and women. Potential interventions include: Public health promotion activities such as advocacy, economic empowerment and capacity building programmes for women and girls particularly in rural communities.
\end{abstract}

Keywords: Perception, Traditional Practices, Discrimination, Culture, Advocacy

\section{Introduction}

There is an encouraging and a growing international awareness that harmful traditional values and practices act as root causes for discrimination and violence against girls and women. Several studies both scientific and social attest the fact that value based discrimination is systemic and universal. The reports of the United Nations Special Rapporteur on Traditional Practices Affecting the Health of Women and Girls (1989) have presented compelling evidences of discrimination and violence against girls based on long upheld social values and practices. The socializing processes observed for boys and girls are designed and rigorously applied to instill a feeling of superiority to boys while girls are groomed to accept subjugation and inferiority with apathy. This established patriarchal system has long endured the passage of time cutting across geographical boundaries as well as religious and class differences. While this unfortunate situation is universal, the manifestations of expression of discrimination and the degrees of violence against girls vary from society to society $(1,3,19)$.

Despite the national, regional and international legislation and frameworks mentioned, universal attitudes of patriarchy and male dominance often engender a culture of violence in which women and children are the victims (4). The incidence of maternal mortality has increased in many parts of the world including sub-Saharan African (SSA) region for a variety of socio-cultural reasons [5]. Maternal mortality is defined as death of a woman while pregnant or within forty two days (or six weeks) of termination of that pregnancy regardless of the site, duration or outcome of the pregnancy or its management, but not from accidental causes. From the estimate, each year 585,000 women die from causes related to pregnancy and childbirth (5). 
Maternal mortality estimate for Nigeria is among the highest in the world and it is put at between 800 and 1,500 deaths per 100, 000 live births. It was as a result of these high maternal mortality rates that safe motherhood initiative (SMI) was officially launched at an international conference held in Nairobi, Kenya in 1987 and in Nigeria 1990. This was part of global goal to reduce maternal death by 50 per cent by the year 2000. Since then awareness of the problem has been raised among policymakers, health professionals and the general public (5). Harmful traditional practices contributed to the high rates of maternal mortality in Nigeria (20).

Harmful traditional practices have been defined as all practices done deliberately by men on the body or the psyche of human beings for no therapeutic purpose, but rather for cultural motives and which have harmful consequences on the health and the rights of the victims (6). In the same vein,harmful traditional practices refer to all forms of physical or psychological violence that prejudice the bodily integrity or mental well-being of women or girls on the basis of their inferior position in the social grouping that are considered to be long-established and community accepted practices deserving tolerance and respect (3).

A wide range of harmful cultural practices (HTPs) affecting maternal and child health exist in Nigeria. They include female genital mutilation-FGM, early forced marriage, food/nutritional taboos, abdominal massage, widowhood rites, sororate and levirate, patronage of traditional birth attendants, insertion of toxic herbs, and preference for the male child (7).

FGM is the partial or total removal of the external female genital or other injury to female genital organ for cultural, religious or other non-therapeutic reason (8). FGM has been discovered to pose serious health hazards for the girl-child or woman, inflicting pain, trauma and body injuries (9). The procedures for FGM can cause severe bleeding and problems urinating, and later cysts, infections, infertility as well as complications in childbirth and increased risk of newborn deaths. More than 125 million girls and women alive today have been cut in the 29 countries in Africa and Middle East where FGM is concentrated (10). FGM is mostly carried out on young girls sometimes between infancy and age 15 . Whatever reasons (psychosocial, sociological, hygiene and aesthetics, religious and others) may be given for the practice of FGM, such reasons are untenable because FGM undermines the well-being of girls and women in Nigeria including women in Oru-West LGA. Thus, FGM is a violation of women and girl's rights irrespective of the type of FGM.

Early forced marriage is usually agreed upon and consummated before the girl is 18 years old, with her sexual organs not yet mature, and her consent irrelevant, early marriage is always a forced marriage and its outcome always a tragedy for the victim. For that reason, early marriage compares easily with child trafficking and as such, it deserves particular attention. Consequences of early/forced marriages include: domestic violence and rape; undesired pregnancies; illegal termination of pregnancies ;inadequate or even lack of pregnancy follow-up and antenatal care leading to highly risky delivery, and possibly to the death of the expecting young mother $(6,10)$.

Food taboos refer to traditionally forbidden food which is enforced against a given social group (especially women and children). These forbidden food items are generally known to be rare and delicious food (eggs, meats, fish...). These food restrictions are often a traditional way of managing rare food items. The consequences are among other things: malnutrition, small birth weight, infections, all manner of diseases, and sometimes death [6].

Forced feeding comprises forced over-feeding of girls and women for the main purpose of gaining weight or "adding flesh", with a view to exact a substantial bride price or dowry. Forced feeding is also associated forced marriage. This practice compromises the girl's health which is sacrificed on the altar of profit-making because forced feeding makes the girls susceptible to obesity which subsequently may lead to metabolic disorders such as diabetes, hypertension and so on (6).

Sororate is a situation whereby a deceased wife is replaced by her younger sister. Levirate is a practice which consists of marrying a widow to the brother of her deceased husband. These two harmful traditional practices are as widespread as early marriages/forced marriages, and have serious consequences on partners' health, since the cause of deaths is not usually taken into account. Infectious and transmittable diseases such as STIs and HIV/AIDS are thus propagated in the concerned families with disastrous consequences (6).

Another harmful traditional practice is widowhood rites. After the death of the husband, his widow is suspected to have been the cause of his death. She is then forced by tradition into a process of proving her innocence, and she must undergo extremely distressing rites, such as drinking the water used to wash the dead body and sleeping with the corpse for a specified number of days. The victim is denied sleep, food and appropriate care (6). Son preference is one of the principal forms of discrimination and one which has farreaching implications for women is the preference accorded to the boy-child over the girl child. This practice denies the girl-child good health, education, recreation, economic opportunity and the right to choose her partner (6).

In most African settings including Nigeria where HTPs are observed, personal grief of loss and other humiliating cultural practices that a widow undergoes as rites of widowhood culminate into deteriorating health of many young and older women. Most widows also experience failing health due primarily to economic hardship, isolation, and stress they experience to provide for themselves and their children. Some obnoxious cultural practices are also most unhygienic. For instance, the practice that demands that the widow drink water that was used to wash her husband's corpse as a swearing to oath for indictment or exoneration for the husband's death poses severe health risks for the woman. This may have a resultant effect of the bereaved having disabling chronic conditions. Other health risks associated with HTPs may be onset of terminal diseases or mental disorders. 
Individuals' perceive social concepts or issues such as harmful traditional practices differently. Their perception of culturally or traditionally entrenched issues as harmful traditional practices may either perpetuate or assist to eliminate these practices. Perception has been defined as the process by which organisms interpret and organize sensation to produce a meaningful experience of the world (11). Sensation usually refers to the immediate, relatively unprocessed result of stimulation of sensory receptors in the eyes, ears, nose, tongue, or skin. Perception, on the other hand, better describes one's ultimate experience of the world and typically involves further processing of sensory input. Perception is also viewed as the process of attaining awareness or understanding of the environment by organizing and interpreting sensory information (12). Perception also involves signals in the nervous system, which in turn result from physical stimulation of the sense organs (12). Perception depends on complex functions of the nervous system, but subjectively seems mostly effortless because this processing happens outside conscious awareness. In this study, perception refers to awareness or understanding women possess in relation harmful traditional practices in Oru-West LGA, Imo State.

Theories are significant not only because they provide diverse explanations and clarity of health issues, but because each model or theory had clear implications for responses and interventions by practitioners and policy makers. If there is no common understanding of a problem, responses will not be consistent and are likely to conflict. So this can undermine the quality of service provision, safety and initiatives for social change. Therefore theoretical approaches are experienced in explaining any public health problems because they are supported by legitimate evidence. With this in view, the framework for understanding perception of HTPs among women of childbearing age (WCBA) as used in this study is the Social Perception Theory (SPT).

Social Perception Theory (SPT) in psychology and other cognitive sciences is that part of perception that allows people to understand the individuals and groups of their social world, and thus an element of social cognition (13). It allows people to determine how others affect their personal lives. While social perceptions can be flawed, they help people to form impressions of others by making the necessary information available to assess what people are like. Missing information is filled in by using an implicit personality theory: if a person is observed to have one particular trait, observers tend to assume that he or she has other traits related to this observed one. These assumptions help to "categorize" people and then infer additional facts and predict behaviour (14). Social perceptions are also interlinked with self-perceptions. Both are influenced by self-motives. Society has the desire to achieve beneficial outcomes for the self and to maintain a positive self-image, both for personal psychic benefits and because we know that others perceive us as well. It is human nature to want to create a good impression on others, almost as if self-perceptions are others' social perceptions (15).
Reproductive health including maternal health often focuses on the reproductive age span (generally considered to be between the ages of 15 and 44 years or 15 and 49 years) (16-17). These women require adequate care and access to equipped health facilities because they are easily susceptible to mortality if not adequately catered for (1).

Oru West Local Government Area (LGA) was established in 1996 by Imo State Government, with its headquarters at Mgbidi. The LGA comprises 20 autonomous communities. The LGA does not have a general hospital but has 13 primary health centers. Many women of childbearing age are ignorant of the adverse health effects of harmful traditional practices because certain traditional norms and influences of community leaders (custodians of ancestral traditions) compelled them to succumb to age-long traditions regardless of their attendant consequences. This unprecedented trend may lead to increase in maternal mortality among women in Oru West LGA. Therefore, the researchers sought to ascertain perception of harmful traditional practices among women of childbearing age in Oru West LGA, Imo State.

\section{Purpose of the Study}

The main purpose of the study was to determine perception of harmful traditional practices affecting maternal and child health among women of childbearing age in Oru West LGA, Imo State. Specifically, the following objectives were formulated to guide the study:

1. Ascertain perception of harmful traditional practices among women of child bearing age in Oru West LGA;

2. Ascertain perception of harmful traditional practices affecting maternal and child health among women of child bearing age in Oru West LGA based on age, and

3. determine perception of harmful traditional practices among women of child bearing age in Oru West LGA based on level of education.

Based on the objectives of the study, the following research objectives and null hypotheses were formulated

1. What is the perception of harmful traditional practices among women of childbearing age in Oru West LGA?

2. What is the perception of harmful traditional practices among women of childbearing age based on age?

3 . What is the perception of harmful traditional practices among women of childbearing age based on their level of education?

Hypotheses

1. There is no significant difference in the perceived harmful traditional practices among women of child bearing age based on age.

2. There is no significant difference in the perceived of harmful traditional practices among women of child bearing age based on level of education.

\section{Methods and Materials}

Descriptive survey research design was utilized for the study. The population of the study comprised 31,838 
registered women of child bearing age in Oru West LGA, Imo State (Oru West Health LGA Office, 2014). The population also comprised 13 government health facilities (PHCs) which included: Aji Health Centre, Amaofuo Health Centre, Ibiasogbe Health Centre, Ihitoha Health Post, Mgbidi Health Centre, Nnemkpi Health Centre, Ohapku Health Centre, Otulu Health Centre, Ozara Health Centre, Amorie Ubulu Health Centre, Ubulu Health Centre, Ubulu Health Post, and Uzinaumu Health Centre. A sample of 384 women of childbearing age was used for the study. The sample size was determined using Fisher's (Vaughan et al., 1989) sample size determination formula. The formula and calculation of the sample size are illustrated below:

$$
\mathrm{ME}=\mathrm{z} \sqrt{\frac{p(1-p)}{n}}
$$

Where:

$\mathrm{ME}$ is the desired margin of error

$\mathrm{z}$ is the $\mathrm{z}$-score, i.e. 0.05 for a $95 \%$ confidence interval

$\mathrm{p}$ is our prior judgment of the correct value of prevalence of expected attribute $(50 \%$ of women expected to have experienced HTPs)

$\mathrm{n}$ is the sample size ( to be found )

So in this case we set ME equal to $0.05, z=1.96$ and $p$ $=0.5$, and $\mathrm{n}$ becomes

$$
\begin{gathered}
0.05=1.96 \sqrt{0.5}(1-0.5) / \mathrm{n} \\
0.5 \times 0.5 / \mathrm{n}=(0.05 / 1.96)^{2} \\
0.25 / \mathrm{n}=0.00065 \\
\mathrm{n}=0.25 / 0.00065=384
\end{gathered}
$$

The multistage sampling procedure was adopted to select the sample. The first stage involved the use of simple random sampling technique of balloting without replacement to select six primary health care centres (PHCs) out of the existing 13 health facilities. The six sampled health facilities included: Aji Health Centre, Mgbidi Health Centre, Nnemkpi Health Centre, Otulu Health Centre, Ozara Health Centre and Uzinaumu Health Centre. The second stage involved the use of stratified random sampling technique to categorize the health facilities into urban and rural health facilities. After this procedure, four health facilities (Aji Health Centre, Nnemkpi Health Centre, Ozara Health Centre and Otulu Health Centre) and two health facilities are located in the rural areas (Mgbidi Health Centre and Uzinaumu Health Centre). The third stage involved the use of purposive sampling technique to select 64 women of childbearing age

in each of the six selected health facilities.

\section{Research Instrument and Data Collection}

A 24-item researcher design structured questionnaire on perception of harmful traditional practices among women of childbearing age in Oru West LGA, Imo State was used to generate quantitative data. The questionnaire comprised two major sections, namely: Section A and Section B. Section A generated information on social demographic variables (age, and level of education) of respondents. Section B generated information on perception of harmful traditional practices among women. This section contained 21 items which were scored on a dichotomous response option of Yes or No. Items in the questionnaire were validated by three experts in the Department of Public Health, Madonna University Elele, Rivers State, Nigeria. Split-half and Spearman-Brown correction formula statistics were utilized to establish the reliability co-efficient of the instrument, which was 0.81 .

The investigators presented introduction letter to the Head, Health Division Oru West LGA, and Matrons of the various Primary Health Care Centres in Oru West LGA. Data collection was carried out through the administration of structured questionnaire on the women. The investigators and research assistants were used for administering and retrieval of copies of the questionnaire from respondents. The investigators and research assistants visited all sampled Primary Health Care Centres-PHCs and administered questionnaire copies on respondents on the spot. The researchers and their assistants went round to offer explanations to any confused respondent seeking clarifications. This was strictly conducted without coercion but based on respondents' volition. Mothers were requested to drop completed copies of the questionnaire into a retrieval bag. This helped in ensuring anonymity of the responses. All the 384 copies of the questionnaire that were distributed were returned representing $100 \%$ return rate. Data were analysed using Statistical Package for Social Sciences (SPSS version 20). The research questions were answered using frequencies and percentages while the null hypotheses were tested using

\begin{tabular}{|c|c|c|c|c|c|}
\hline \multirow{2}{*}{$\mathbf{S} / \mathbf{N}$} & \multirow{2}{*}{ Items } & \multicolumn{2}{|l|}{ Yes } & \multicolumn{2}{|l|}{ No } \\
\hline & & $\mathbf{f}$ & $\%$ & f & $\%$ \\
\hline 1 & Female circumcision is a necessity in the society & 178 & 46.4 & 206 & 53.6 \\
\hline 2 & Female circumcision has adverse health effects & 280 & 72.9 & 104 & 27.1 \\
\hline 3 & Female circumcision affects reproductive health & 268 & 69.8 & 116 & 30.2 \\
\hline 4 & Early marriage is inimical to teenage girls & 154 & 40.1 & 230 & 59.9 \\
\hline 5 & There are benefits associated with early marriage & 179 & 46.6 & 205 & 53.4 \\
\hline 6 & Early marriage enhances growth and maturity & 154 & 40.1 & 230 & 59.9 \\
\hline
\end{tabular}
chi-square $\left(\chi^{2}\right)$ at .05 level of significance and at the appropriate degrees of freedom.

\section{Results and Discussion}

Table 1. Frequency and Percentage of Perceived Harmful Traditional Practices among Women of Childbearing Age (n=384). 


\begin{tabular}{|c|c|c|c|c|c|}
\hline \multirow{2}{*}{$\mathbf{S} / \mathbf{N}$} & \multirow{2}{*}{ Items } & \multicolumn{2}{|l|}{ Yes } & \multicolumn{2}{|l|}{ No } \\
\hline & & f & $\%$ & f & $\%$ \\
\hline 7 & Inheritance should only be allocated for male children & 228 & 59.4 & 156 & 40.6 \\
\hline 8 & Security of the mother depends on having a male child & 320 & 83.3 & 64 & 16.7 \\
\hline 9 & Male children are more important than female children in a family & 155 & 40.4 & 229 & 59.6 \\
\hline 10 & A widow should be blamed for the husband's death & 182 & 47.4 & 202 & 52.6 \\
\hline 11 & A widow should not inherit her husband's properties & 180 & 46.9 & 204 & 53.1 \\
\hline 12 & A widow should be maltreated by her husband's family & 141 & 36.7 & 243 & 63.3 \\
\hline 14 & A widow should be married to her late husband's brother & 162 & 42.2 & 222 & 57.8 \\
\hline 15 & A widow can bear children for her late husband's family through another man & 215 & 56.0 & 169 & 44.0 \\
\hline 16 & Teenage pregnancy has its advantages & 133 & 34.6 & 251 & 65.4 \\
\hline 17 & Teenage pregnancy should be encouraged to boost financial status of the family & 168 & 43.8 & 216 & 56.3 \\
\hline 18 & Teenage pregnancy has its adverse effects & 212 & 55.2 & 172 & 44.8 \\
\hline 19 & Scarification should be perpetuated as a traditional cosmetic practice & 221 & 57.6 & 163 & 42.4 \\
\hline 20 & Scarification should be performed with unsterilized instruments & 179 & 46.6 & 205 & 53.4 \\
\hline 21 & $\%$ Average & & 49.3 & & 50.7 \\
\hline
\end{tabular}

Table 1 shows that overall, 49.3 per cent of women of practices are harmful to women. childbearing age perceived that the identified traditional

Table 2. Frequency and Percentage of Perception of Harmful Traditional Practices among Women of Childbearing Age Based on their Age (n=384).

\begin{tabular}{|c|c|c|c|c|c|}
\hline \multirow{4}{*}{$\mathbf{S} / \mathbf{N}$} & \multirow{4}{*}{ Items } & \multicolumn{4}{|c|}{ Age } \\
\hline & & \multicolumn{2}{|c|}{$15-22 y r s(n=18)$} & \multicolumn{2}{|c|}{ 23-30yrs $(n=133)$} \\
\hline & & Yes & No & Yes & No \\
\hline & & $\mathbf{f}(\%)$ & $f(\%)$ & $f(\%)$ & f (\%) \\
\hline 1 & Female circumcision is a necessity in the society & $7(38.9)$ & $11(61.1)$ & $68(51.1)$ & $65(48.9)$ \\
\hline 2 & Female circumcision has adverse health effects & $11(61.1)$ & $7(38.9)$ & $93(69.9)$ & $40(36.1)$ \\
\hline 3 & Female circumcision affects reproductive health & $11(61.1)$ & $7(38.9)$ & $88(66.2)$ & $45(33.8)$ \\
\hline 4 & Early marriage is inimical to teenage girls & $7(38.9)$ & 11(61.1) & $54(40.6)$ & $79(59.4)$ \\
\hline 5 & There are benefits associated with early marriage & $8(44.4)$ & $10(55.6)$ & $61(45.9)$ & $72(54.1)$ \\
\hline 6 & Early marriage enhances growth and maturity & $8(44.4)$ & $10(55.6)$ & $53(39.8)$ & $80(60.2)$ \\
\hline 7 & Inheritance should only be allocated for male children & $9(50.0)$ & $9(50.0)$ & $84(63.2)$ & $49(36.8)$ \\
\hline 8 & Security of the mother depends on having a male child & $14(77.8)$ & $4(22.2)$ & $113(85.0)$ & $20(15.0)$ \\
\hline 9 & Male children are more important than female children & $9(50.0)$ & $9(50.0)$ & $57(42.9)$ & $76(57.1)$ \\
\hline 10 & A widow should be blamed for the husband's death & $11(61.1)$ & $7(38.9)$ & $64(48.1)$ & $69(51.9)$ \\
\hline 11 & A widow should not inherit her husband's properties & $9(50.0)$ & $9(50.0)$ & $65(48.9)$ & $68(51.1)$ \\
\hline 12 & A widow should be maltreated by her husband's family & $7(38.9)$ & $11(61.1)$ & $49(36.8)$ & $84(63.2)$ \\
\hline 13 & A late wife should be replaced by her younger sister & $3(16.7)$ & $15(83.3)$ & $35(26.3)$ & 98(73.7) \\
\hline 14 & A widow should be married to her late husband's brother & $10(55.6)$ & $8(44.4)$ & $52(39.1)$ & $81(60.9)$ \\
\hline 15 & A widow can bear children for her late husband's family through another man & $8(44.4)$ & $10(55.6)$ & $77(57.9)$ & $56(42.1)$ \\
\hline 16 & Teenage pregnancy has its advantages & $6(33.3)$ & $12(66.7)$ & $39(29.3)$ & $94(70.7)$ \\
\hline 17 & Teenage pregnancy should be encouraged to boost financial status of the family & $10(55.6)$ & $8(44.4)$ & $60(45.1)$ & $73(54.9)$ \\
\hline 18 & Teenage pregnancy has its adverse effects & $8(44.4)$ & $10(55.6)$ & $78(58.6)$ & $55(41.4)$ \\
\hline 19 & Scarification should be perpetuated as a traditional cosmetic practice & $13(72.2)$ & $5(27.8)$ & $75(56.4)$ & $58(43.6)$ \\
\hline 20 & Scarification should be performed with unsterilized instruments & $12(66.7)$ & $6(33.3)$ & $57(42.9)$ & $76(57.1)$ \\
\hline \multirow[t]{2}{*}{21} & $\begin{array}{l}\text { Food taboos such as avoidance of snails, mushrooms and other edibles is } \\
\text { acceptable }\end{array}$ & $13(72.2)$ & $5(27.8)$ & $75(56.4)$ & $58(43.6)$ \\
\hline & $\%$ Average & 51.3 & 48.7 & $\mathbf{5 0 . 0}$ & $\mathbf{5 0 . 0}$ \\
\hline
\end{tabular}

Table 2. (Continue)

\begin{tabular}{|c|c|c|c|c|c|}
\hline \multirow{4}{*}{$\mathbf{S} / \mathbf{N}$} & \multirow{4}{*}{ Items } & \multicolumn{4}{|c|}{ Age } \\
\hline & & \multicolumn{2}{|c|}{ 31-38yrs $(n=192)$} & \multicolumn{2}{|c|}{$39-46 y r s(n=41)$} \\
\hline & & Yes & No & Yes & No \\
\hline & & f (\%) & f (\%) & f (\%) & f (\%) \\
\hline 1 & Female circumcision is a necessity in the society & $86(44.8)$ & $106(55.2)$ & $17(41.5)$ & $24(58.5)$ \\
\hline 2 & Female circumcision has adverse health effects & $135(70.3)$ & $67(29.7)$ & $41(100)$ & $0(0.0)$ \\
\hline 3 & Female circumcision affects reproductive health & $128(66.7)$ & $64(33.3)$ & $41(100)$ & $0(0.0)$ \\
\hline 4 & Early marriage is inimical to teenage girls & $59(30.7)$ & $133(69.3)$ & $34(82.9)$ & $7(17.1)$ \\
\hline 5 & There are benefits associated with early marriage & $92(47.9)$ & $100(52.1)$ & $18(43.9)$ & $23(56.1)$ \\
\hline 6 & Early marriage enhances growth and maturity & $68(35.4)$ & $124(64.6)$ & $25(61.0)$ & $16(69.0)$ \\
\hline 7 & Inheritance should only be allocated for male children & $103(53.6)$ & $89(46.4)$ & $32(78.0)$ & $9(22.0)$ \\
\hline 8 & Security of the mother depends on having a male child & $152(79.2)$ & $40(20.8)$ & $41(100)$ & $0(0.0)$ \\
\hline 9 & Male children are more important than female children & $74(38.5)$ & $118(61.5)$ & $15(36.6)$ & $26(63.4)$ \\
\hline 10 & A widow should be blamed for the husband's death & $99(51.6)$ & $93(48.4)$ & $8(19.5)$ & $33(80.5)$ \\
\hline
\end{tabular}




\begin{tabular}{|c|c|c|c|c|c|}
\hline \multirow{4}{*}{$\mathbf{S} / \mathbf{N}$} & \multirow{4}{*}{ Items } & \multicolumn{4}{|l|}{ Age } \\
\hline & & \multicolumn{2}{|c|}{ 31-38yrs (n=192) } & \multicolumn{2}{|c|}{ 39-46yrs $(n=41)$} \\
\hline & & Yes & No & Yes & No \\
\hline & & $\mathbf{f}(\%)$ & $\mathbf{f}(\%)$ & $\mathbf{f}(\%)$ & $\mathbf{f}(\%)$ \\
\hline 11 & A widow should not inherit her husband's properties & $83(43.2)$ & $109(56.8)$ & 23(56.1) & 18(43.9) \\
\hline 12 & A widow should be maltreated by her husband's family & $62(32.3)$ & $130(67.7)$ & $23(56.1)$ & 18(43.9) \\
\hline 13 & A late wife should be replaced by her younger sister & $28(14.6)$ & 164(85.4) & $23(56.1)$ & 18(43.9) \\
\hline 14 & A widow should be married to her late husband's brother & 83(43.2) & $109(56.8)$ & $17(41.5)$ & $24(58.5)$ \\
\hline 15 & A widow can bear children for her late husband's family through another man & $97(50.5)$ & $95(49.5)$ & $33(80.5)$ & $8(19.5)$ \\
\hline 16 & Teenage pregnancy has its advantages & $81(42.2)$ & $111(57.8)$ & $7(17.1)$ & 34(82.9) \\
\hline 17 & $\begin{array}{l}\text { Teenage pregnancy should be encouraged to boost financial status of the } \\
\text { family }\end{array}$ & $83(43.2)$ & $109(56.8)$ & $15(36.6)$ & $26(63.4)$ \\
\hline 18 & Teenage pregnancy has its adverse effects & $96(50.0)$ & $96(50.0)$ & $30(73.2)$ & $11(26.8)$ \\
\hline 19 & Scarification should be perpetuated as a traditional cosmetic practice & 115(59.9) & $77(40.1)$ & $18(43.9)$ & $23(56.1)$ \\
\hline 20 & Scarification should be performed with unsterilized instruments & 103(53.6) & $89(46.4)$ & $7(17.1)$ & 34(82.9) \\
\hline \multirow[t]{2}{*}{21} & $\begin{array}{l}\text { Food taboos such as avoidance of snails, mushrooms and other edibles is } \\
\text { acceptable }\end{array}$ & $78(40.6)$ & $114(59.4)$ & $14(34.1)$ & $27(65.9)$ \\
\hline & $\%$ Average & 47.2 & 52.8 & 56.0 & 44.0 \\
\hline
\end{tabular}

Results in Table 2 indicate that women in age groups 3946 years $(56 \%)$ and $31-38$ years $(52.8 \%)$, more than women in age groups $15-22$ years $(51.3 \%)$ and $23-30$ years $(50 \%)$ respectively perceived traditional practices to be harmful to women

Table 3. Frequency and Percentage of perception of Harmful Traditional Practices among Women of Childbearing Age Based on Level of Education ( $n=384$ )

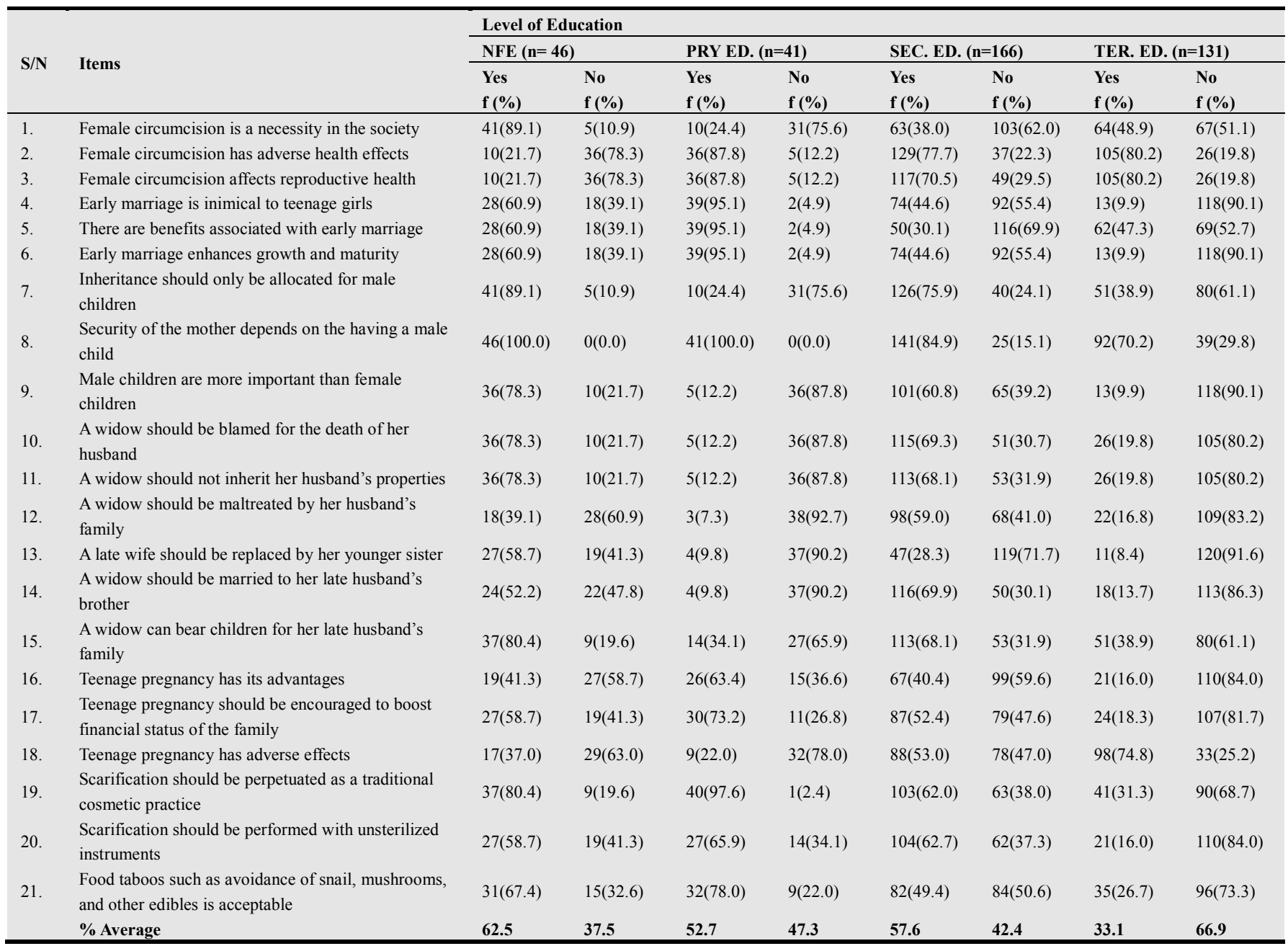

Table 3 shows that 62.5 per cent of women with no formal education-NFE, 57.6 per cent of women with secondary education, 52.7 per cent of women with primary education and 33.1 per cent of women with tertiary education perceived the highlighted traditional practices as harmful to women. 
Table 4. Summary of Chi-square Analysis of No Significant Difference in the Perception of Harmful Traditional Practices among Women Based on Age

\begin{tabular}{|c|c|c|c|c|c|c|c|c|c|c|c|c|}
\hline \multirow{4}{*}{$\mathbf{S} / \mathbf{N}$} & \multirow{4}{*}{ Items } & \multicolumn{11}{|c|}{ AGE (years) } \\
\hline & & \multicolumn{4}{|c|}{$15-22$ years $(n=18)$} & \multicolumn{4}{|c|}{$23-30$ years $(n=133)$} & \multirow{3}{*}{$\chi 2$-cal } & \multirow{3}{*}{ P - val. } & \multirow{3}{*}{ *Dec. } \\
\hline & & \multicolumn{2}{|c|}{ Yes } & \multicolumn{2}{|c|}{ No } & \multicolumn{2}{|c|}{ Yes } & \multicolumn{2}{|c|}{ No } & & & \\
\hline & & $\mathbf{O}$ & $\mathbf{E}$ & $\mathbf{O}$ & $\mathbf{E}$ & $\mathbf{O}$ & $\mathbf{E}$ & $\mathbf{O}$ & $\mathbf{E}$ & & & \\
\hline 1. & Female circumcision is a necessity in the society & 7 & 8.3 & 11 & 9.7 & 68 & 61.7 & 65 & 71.3 & 2.205 & .531 & $* *$ \\
\hline 2. & Female circumcision has adverse health effects & 11 & 13.1 & 7 & 4.9 & 93 & 97.0 & 40 & 36.0 & 17.761 & .001 & * \\
\hline 3. & Female circumcision affects reproductive health & 11 & 12.6 & 7 & 5.4 & 88 & 92.8 & 45 & 40.2 & 20.108 & .001 & * \\
\hline 4. & Early marriage is inimical to teenage girls & 7 & 7.2 & 11 & 10.8 & 54 & 53.3 & 79 & 79.7 & 38.350 & .001 & * \\
\hline 5. & There are benefits associated with early marriage & 8 & 8.4 & 10 & 9.6 & 61 & 62.0 & 72 & 71.0 & 0.316 & .957 & $* *$ \\
\hline 6. & Early marriage enhances growth and maturity & 8 & 7.2 & 10 & 10.8 & 53 & 53.3 & 80 & 79.7 & 9.336 & .025 & * \\
\hline 7. & Inheritance should only be allocated for male children & 9 & 10.7 & 9 & 7.3 & 84 & 79.0 & 49 & 54.0 & 9.985 & .019 & * \\
\hline 8. & Security of the mother depends on having a male child & 14 & 15.0 & 4 & 3.0 & 113 & 110.8 & 20 & 22.2 & 11.254 & .010 & * \\
\hline 9. & Male children are more important than female children & 9 & 7.3 & 9 & 10.7 & 57 & 53.7 & 76 & 79.3 & 1.546 & .672 & $* *$ \\
\hline 10. & A widow should be blamed for her husband's death & 11 & 8.5 & 7 & 9.5 & 64 & 63.0 & 69 & 70.0 & 15.509 & .001 & * \\
\hline 11. & A widow should not inherit her husband's properties & 9 & 8.4 & 9 & 9.6 & 65 & 62.3 & 68 & 70.7 & 2.709 & .439 & $* *$ \\
\hline 12. & A widow should be maltreated by her husband's family & 7 & 6.6 & 11 & 11.4 & 49 & 48.8 & 84 & 84.2 & 8.283 & .041 & * \\
\hline 13. & A late wife should be replaced by her younger sister & 3 & 4.2 & 15 & 13.8 & 35 & 30.8 & 98 & 102.2 & 34.084 & .001 & * \\
\hline 14. & A widow should be married to her late husband's brother & 10 & 7.6 & 8 & 10.4 & 52 & 56.1 & 81 & 76.9 & 1.924 & .586 & $* *$ \\
\hline 15. & A widow can bear children for her late husband's family & 8 & 10.1 & 10 & 7.9 & 77 & 74.5 & 56 & 58.5 & 13.486 & .004 & * \\
\hline 16. & Teenage pregnancy has its advantages & 6 & 6.2 & 12 & 11.8 & 39 & 46.1 & 94 & 86.9 & 12.094 & .007 & * \\
\hline 17. & $\begin{array}{l}\text { Teenage pregnancy should be encouraged to boost financial } \\
\text { status of the family }\end{array}$ & 10 & 7.9 & 8 & 10.1 & 60 & 58.2 & 73 & 74.8 & 1.996 & .573 & $* *$ \\
\hline 18. & Teenage pregnancy has adverse effects & 8 & 9.9 & 10 & 8.1 & 78 & 73.4 & 55 & 59.6 & 8.935 & .030 & * \\
\hline 19. & $\begin{array}{l}\text { Scarification should be perpetuated as a traditional cosmetic } \\
\text { practice }\end{array}$ & 13 & 10.4 & 5 & 7.6 & 75 & 76.5 & 58 & 56.5 & 5.218 & .157 & $* *$ \\
\hline 20. & Scarification should be performed with unsterilized instruments & 12 & 8.4 & 6 & 9.6 & 57 & 62.0 & 76 & 71.0 & 21.855 & .001 & * \\
\hline 21. & $\begin{array}{l}\text { Food taboos such as avoidance of snail, mushrooms, and other } \\
\text { edibles is acceptable }\end{array}$ & 13 & 8.4 & 5 & 9.6 & 75 & 62.3 & 58 & 70.7 & $\begin{array}{l}15.160 \\
\mathbf{1 2 . 0 0 5}\end{array}$ & $\begin{array}{l}.002 \\
.193\end{array}$ & $* *$ \\
\hline
\end{tabular}

Table 4. (Continue)

\begin{tabular}{|c|c|c|c|c|c|c|c|c|c|c|c|c|}
\hline \multirow{4}{*}{$\mathbf{S} / \mathbf{N}$} & \multirow{4}{*}{ Items } & \multicolumn{11}{|c|}{ AGE (years) } \\
\hline & & \multicolumn{4}{|c|}{$31-38$ years $(n=192)$} & \multicolumn{4}{|c|}{$39-46$ years $(n=41)$} & \multirow{3}{*}{$\chi 2$-cal } & \multirow{3}{*}{$\begin{array}{l}\mathbf{P}- \\
\text { val. }\end{array}$} & \multirow{3}{*}{ *Dec. } \\
\hline & & \multicolumn{2}{|c|}{ Yes } & \multicolumn{2}{|l|}{ No } & \multicolumn{2}{|c|}{ Yes } & \multicolumn{2}{|l|}{ No } & & & \\
\hline & & $\mathbf{O}$ & $\mathbf{E}$ & $\mathbf{O}$ & $\mathbf{E}$ & $\mathbf{O}$ & $\mathbf{E}$ & $\mathbf{O}$ & $\mathbf{E}$ & & & \\
\hline 1. & Female circumcision is a necessity in the society & 86 & 89.0 & 106 & 103.0 & 17 & 19.0 & 24 & 22.0 & 2.205 & .531 & $* *$ \\
\hline 2. & Female circumcision has adverse health effects & 135 & 140.0 & 57 & 52.0 & 41 & 29.9 & 0 & 11.1 & 17.761 & .001 & $*$ \\
\hline 3. & Female circumcision affects reproductive health & 128 & 134.0 & 64 & 58.0 & 41 & 28.6 & 0 & 12.4 & 20.108 & .001 & * \\
\hline 4. & Early marriage is inimical to teenage girls & 59 & 77.0 & 133 & 115.0 & 34 & 16.4 & 7 & 24.6 & 38.350 & .001 & * \\
\hline 5. & There are benefits associated with early marriage & 92 & 89.5 & 100 & 102.5 & 18 & 19.1 & 23 & 21.9 & 0.316 & .957 & $* *$ \\
\hline 6. & Early marriage enhances growth and maturity & 68 & 77.0 & 124 & 115.0 & 25 & 16.4 & 16 & 24.6 & 9.336 & .025 & * \\
\hline 7. & Inheritance should only be allocated for male children & 103 & 114.0 & 89 & 78.0 & 32 & 24.3 & 9 & 16.7 & 9.985 & .019 & $*$ \\
\hline 8. & Security of the mother depends on having a male child & 152 & 160.0 & 40 & 32.0 & 41 & 34.2 & 0 & 6.8 & 11.254 & .010 & * \\
\hline 9. & Male children are more important than female children & 74 & 77.5 & 118 & 114.5 & 15 & 16.5 & 26 & 24.5 & 1.546 & 672 & $* *$ \\
\hline 10. & A widow should be blamed for her husband's death & 99 & 91.0 & 93 & 101.0 & 8 & 19.4 & 33 & 21.6 & 15.509 & .001 & * \\
\hline 11. & A widow should not inherit her husband's properties & 83 & 90.0 & 109 & 102.0 & 23 & 19.2 & 18 & 21.8 & 2.709 & .439 & $* *$ \\
\hline 12. & A widow should be maltreated by her husband's family & 62 & 70.5 & 130 & 121.5 & 23 & 15.1 & 18 & 25.9 & 8.283 & .041 & * \\
\hline 13. & A late wife should be replaced by her younger sister & 28 & 44.5 & 164 & 147.5 & 23 & 9.5 & 18 & 31.5 & 34.084 & .001 & * \\
\hline 14. & A widow should be married to her late husband's brother & 83 & 81.0 & 109 & 111.0 & 17 & 17.3 & 24 & 23.7 & 1.924 & .586 & $* *$ \\
\hline 15. & A widow can bear children for her late husband's family & 97 & 107.5 & 95 & 84.5 & 33 & 23.0 & 8 & 18.0 & 13.486 & .004 & * \\
\hline 16. & Teenage pregnancy has its advantages & 81 & 66.5 & 111 & 125.5 & 7 & 14.2 & 34 & 26.8 & 12.094 & .007 & $*$ \\
\hline 17. & $\begin{array}{l}\text { Teenage pregnancy should be encouraged to boost financial } \\
\text { status of the family }\end{array}$ & 83 & 84.0 & 109 & 108.0 & 15 & 17.9 & 26 & 23.1 & 1.996 & .573 & ** \\
\hline 18. & Teenage pregnancy has adverse effects & 96 & 106.0 & 96 & 86.0 & 30 & 22.6 & 11 & 18.4 & 8.935 & .030 & $*$ \\
\hline 19. & $\begin{array}{l}\text { Scarification should be perpetuated as a traditional cosmetic } \\
\text { practice }\end{array}$ & 115 & 110.5 & 77 & 81.5 & 18 & 23.6 & 23 & 17.4 & 5.218 & .157 & $* *$ \\
\hline 20. & $\begin{array}{l}\text { Scarification should be performed with unsterilized } \\
\text { instruments }\end{array}$ & 103 & 89.5 & 89 & 102.5 & 7 & 19.1 & 34 & 21.9 & 21.855 & .001 & $*$ \\
\hline 21. & $\begin{array}{l}\text { Food taboos such as avoidance of snail, mushrooms, and } \\
\text { other edibles is acceptable }\end{array}$ & 78 & 90.0 & 114 & 102.0 & 14 & 19.2 & 27 & 21.8 & $\begin{array}{l}15.160 \\
12.005\end{array}$ & $\begin{array}{l}.002 \\
.193\end{array}$ & $* *$ \\
\hline
\end{tabular}

* Significant at $\mathrm{P}<.05$

Key

$*$ Dec. $=$ Decision

$*=$ Significant

** =Not Significant 
Table 4 shows the overall $\chi^{2}$ calculated value with its corresponding $\mathrm{P}-$ value for perception of harmful traditional practices among women of childbearing age based on their age $\left(\chi^{2}=12.01, \mathrm{P}=.193\right)$. Since the overall $\mathrm{P}$-value $(\mathrm{P}=.193)$ is greater than .05 level of significance $(\mathrm{P}=.193>.05)$, the null hypotheses of no significant difference in the perception of harmful traditional practices among women of childbearing age based on age was, therefore, rejected. This implies that age of women influenced their perception of harmful traditional practices.

Table 5. Summary of Chi-square Analysis of No Significant Difference in the Perception of HTPs among WCBA Based on Level of Education

\begin{tabular}{|c|c|c|c|c|c|c|c|c|c|c|c|c|}
\hline \multirow{4}{*}{$\mathbf{S} / \mathbf{N}$} & \multirow{4}{*}{ Items } & \multicolumn{8}{|c|}{ Level of Education } & \multirow{4}{*}{$\chi 2$-cal. } & \multirow{4}{*}{ P-val. } & \multirow{4}{*}{ *Dec. } \\
\hline & & \multicolumn{4}{|c|}{ *NFE $(n=46)$} & \multicolumn{4}{|c|}{ *PRY ED. $(n=41)$} & & & \\
\hline & & \multicolumn{2}{|c|}{ Yes } & \multicolumn{2}{|l|}{ No } & \multicolumn{2}{|c|}{ Yes } & \multicolumn{2}{|l|}{ No } & & & \\
\hline & & $\mathbf{O}$ & $\mathbf{E}$ & $\mathbf{O}$ & $\mathbf{E}$ & $\mathbf{O}$ & $\mathbf{E}$ & $\mathbf{O}$ & $\mathbf{E}$ & & & \\
\hline 1. & Female circumcision is a necessity in the society & 41 & 21.3 & 5 & 24.7 & 10 & 19.0 & 31 & 22.0 & 46.845 & .001 & * \\
\hline 2. & Female circumcision has adverse health effects & 10 & 33.5 & 36 & 12.5 & 36 & 29.9 & 5 & 11.1 & 71.015 & .001 & * \\
\hline 3. & Female circumcision affects reproductive health & 10 & 32.1 & 36 & 13.9 & 36 & 28.6 & 5 & 12.4 & 63.398 & .001 & $*$ \\
\hline 5. & There are benefits associated with early marriage & 28 & 21.4 & 18 & 24.6 & 39 & 19.1 & 2 & 21.9 & 60.697 & .001 & * \\
\hline 6. & Early marriage enhances growth and maturity & 28 & 18.4 & 18 & 27.6 & 39 & 16.4 & 2 & 24.6 & 110.982 & .001 & $*$ \\
\hline 7. & Inheritance should only be allocated for male children & 41 & 27.3 & 5 & 18.7 & 10 & 24.3 & 31 & 16.7 & 79.188 & .001 & * \\
\hline 8. & Security of the mother depends on having a male child & 46 & 38.3 & 0 & 7.7 & 41 & 34.2 & 0 & 6.8 & 33.905 & .001 & * \\
\hline 9. & Male children are more important than female children & 36 & 18.6 & 10 & 27.4 & 5 & 16.5 & 36 & 24.5 & 120.310 & .001 & * \\
\hline 10. & A widow should be blamed for the death of her husband & 36 & 21.8 & 10 & 24.2 & 5 & 19.4 & 36 & 21.6 & 109.707 & .001 & * \\
\hline 12. & A widow should be maltreated by her husband's family & 18 & 16.9 & 28 & 29.1 & 3 & 15.1 & 38 & 25.9 & 73.333 & .001 & * \\
\hline 13. & A late wife should be replaced by her younger sister & 27 & 10.7 & 19 & 35.3 & 4 & 9.5 & 37 & 31.5 & 55.272 & .001 & $*$ \\
\hline 14. & A widow should be married to her late husband's brother & 24 & 19.4 & 22 & 26.6 & 4 & 17.3 & 37 & 23.7 & 115.220 & .001 & * \\
\hline 15. & A widow can bear children for her late husband's family & 37 & 25.8 & 9 & 20.2 & 14 & 23.0 & 27 & 18.0 & 44.399 & .001 & $*$ \\
\hline 16. & Teenage pregnancy has its advantages & 19 & 15.9 & 27 & 30.1 & 26 & 14.2 & 15 & 26.8 & 38.336 & .001 & * \\
\hline 17. & Teenage pregnancy should be encouraged to boost financial status & 27 & 20.1 & 19 & 25.9 & 30 & 17.9 & 11 & 23.1 & 58.077 & .001 & * \\
\hline 18. & Teenage pregnancy has adverse effects & 17 & 25.4 & 29 & 20.6 & 9 & 22.6 & 32 & 18.4 & 45.211 & .001 & * \\
\hline 19. & $\begin{array}{l}\text { Scarification should be perpetuated as a traditional cosmetic } \\
\text { practice }\end{array}$ & 37 & 26.5 & 9 & 19.5 & 40 & 23.6 & 1 & 17.4 & 75.060 & .001 & $*$ \\
\hline 20. & Scarification should be performed with unsterilized instruments & 27 & 21.4 & 19 & 24.6 & 27 & 19.1 & 14 & 21.9 & 75.190 & .001 & * \\
\hline \multirow[t]{2}{*}{21.} & $\begin{array}{l}\text { Food taboos such as avoidance of snail, mushrooms, and other } \\
\text { edibles is acceptable }\end{array}$ & 31 & 21.6 & 15 & 24.4 & 32 & 19.2 & 9 & 21.8 & 45.574 & .001 & * \\
\hline & Overall & & & & & & & & & 73.289 & .001 & * \\
\hline
\end{tabular}

Table 5. (Continue)

\begin{tabular}{|c|c|c|c|c|c|c|c|c|c|c|c|c|}
\hline \multirow{4}{*}{$\mathbf{S} / \mathbf{N}$} & \multirow{4}{*}{ Items } & \multicolumn{8}{|c|}{ Level of Education } & \multirow{4}{*}{$\chi^{2}$-cal. } & \multirow{4}{*}{$\begin{array}{l}\text { P- } \\
\text { val. }\end{array}$} & \multirow{4}{*}{ *Dec } \\
\hline & & \multicolumn{4}{|c|}{ *SEC. ED. $(n=166)$} & \multicolumn{4}{|c|}{ *TER ED. $(n=131)$} & & & \\
\hline & & \multicolumn{2}{|c|}{ Yes } & \multicolumn{2}{|l|}{ No } & \multicolumn{2}{|c|}{ Yes } & \multicolumn{2}{|l|}{ No } & & & \\
\hline & & $\mathbf{O}$ & $\mathbf{E}$ & $\mathbf{O}$ & $\mathbf{E}$ & $\mathbf{O}$ & $\mathbf{E}$ & $\mathbf{O}$ & $\mathbf{E}$ & & & \\
\hline 1. & Female circumcision is a necessity in the society & 63 & 76.9 & 103 & 89.1 & 64 & 60.7 & 67 & 70.3 & 46.845 & .001 & $*$ \\
\hline 2. & Female circumcision has adverse health effects & 129 & 121.0 & 37 & 45.0 & 105 & 95.5 & 26 & 35.5 & 71.015 & .001 & $*$ \\
\hline 3. & Female circumcision affects reproductive health & 117 & 115.9 & 49 & 50.1 & 105 & 91.4 & 26 & 39.6 & 63.398 & .001 & $*$ \\
\hline 4. & Early marriage is inimical to teenage girls & 74 & 66.6 & 92 & 99.4 & 13 & 52.5 & 118 & 78.5 & 110.982 & .001 & $*$ \\
\hline 5. & There are benefits associated with early marriage & 50 & 77.4 & 116 & 88.6 & 62 & 61.1 & 69 & 69.9 & 60.697 & .001 & $*$ \\
\hline 6. & Early marriage enhances growth and maturity & 74 & 66.6 & 92 & 99.4 & 13 & 52.5 & 118 & 78.5 & 110.982 & .001 & $*$ \\
\hline 7. & Inheritance should only be allocated for male children & 126 & 98.6 & 40 & 67.4 & 51 & 77.8 & 80 & 53.2 & 79.188 & .001 & $*$ \\
\hline 8. & Security of the mother depends on having a male child & 141 & 138.3 & 25 & 27.7 & 92 & 109.2 & 39 & 21.8 & 33.905 & .001 & $*$ \\
\hline 9. & Male children are more important than female children & 101 & 67.0 & 65 & 99.0 & 13 & 52.9 & 118 & 78.1 & 120.310 & .001 & * \\
\hline 10. & A widow should be blamed for the death of her husband & 115 & 78.7 & 51 & 87.3 & 26 & 62.1 & 105 & 68.9 & 109.707 & .001 & * \\
\hline 11. & A widow should not inherit her husband's properties & 113 & 77.8 & 53 & 88.2 & 26 & 61.4 & 105 & 69.6 & 106.378 & .001 & * \\
\hline 12. & A widow should be maltreated by her husband's family & 98 & 61.0 & 68 & 105.0 & 22 & 48.1 & 109 & 82.9 & 73.333 & .001 & * \\
\hline 13. & A late wife should be replaced by her younger sister & 47 & 38.5 & 119 & 127.5 & 11 & 30.4 & 120 & 100.6 & 55.272 & .001 & $*$ \\
\hline 14. & A widow should be married to her late husband's brother & 116 & 70.0 & 50 & 96.0 & 18 & 55.3 & 113 & 75.7 & 115.220 & .001 & $*$ \\
\hline 15. & A widow can bear children for her late husband's family & 113 & 92.9 & 53 & 73.1 & 51 & 73.3 & 80 & 57.7 & 44.399 & .001 & * \\
\hline 16. & Teenage pregnancy has its advantages & 67 & 57.5 & 99 & 108.5 & 21 & 45.4 & 110 & 85.6 & 38.336 & .001 & $*$ \\
\hline 17. & $\begin{array}{l}\text { Teenage pregnancy should be encouraged to boost } \\
\text { financial status }\end{array}$ & 87 & 72.6 & 79 & 93.4 & 24 & 57.3 & 107 & 73.7 & 58.077 & .001 & * \\
\hline 18. & Teenage pregnancy has adverse effects & 88 & 91.6 & 78 & 74.4 & 98 & 72.3 & 33 & 58.7 & 45.211 & .001 & $*$ \\
\hline 19. & $\begin{array}{l}\text { Scarification should be perpetuated as a traditional } \\
\text { cosmetic practice }\end{array}$ & 103 & 95.5 & 63 & 70.5 & 41 & 75.4 & 90 & 55.6 & 75.060 & .001 & $*$ \\
\hline
\end{tabular}




\begin{tabular}{|c|c|c|c|c|c|c|c|c|c|c|c|c|}
\hline \multirow{4}{*}{$\mathbf{S} / \mathbf{N}$} & \multirow{4}{*}{ Items } & \multicolumn{8}{|c|}{ Level of Education } & \multirow{4}{*}{$\chi^{2}$-cal. } & \multirow{4}{*}{$\begin{array}{l}\text { P- } \\
\text { val. }\end{array}$} & \multirow{4}{*}{ *Dec } \\
\hline & & \multicolumn{4}{|c|}{ *SEC. ED. $(n=166)$} & \multicolumn{4}{|c|}{ *TER ED. $(n=131)$} & & & \\
\hline & & \multicolumn{2}{|c|}{ Yes } & \multicolumn{2}{|c|}{ No } & \multicolumn{2}{|c|}{ Yes } & \multicolumn{2}{|l|}{ No } & & & \\
\hline & & $\mathbf{O}$ & $\mathbf{E}$ & $\mathbf{O}$ & $\mathbf{E}$ & $\mathbf{O}$ & $\mathbf{E}$ & $\mathbf{O}$ & $\mathbf{E}$ & & & \\
\hline 20. & $\begin{array}{l}\text { Scarification should be performed with unsterilized } \\
\text { instruments }\end{array}$ & 104 & 77.4 & 62 & 88.6 & 21 & 61.1 & 110 & 69.9 & 75.190 & .001 & $*$ \\
\hline \multirow[t]{2}{*}{21.} & $\begin{array}{l}\text { Food taboos such as avoidance of snail, mushrooms, and } \\
\text { other edibles is acceptable }\end{array}$ & 82 & 77.8 & 84 & 88.2 & 35 & 61.4 & 96 & 69.6 & 45.574 & .001 & * \\
\hline & Overall & & & & & & & & & 73.289 & .001 & * \\
\hline
\end{tabular}

* Significant at $\mathrm{P}<.05$

Key

$* \mathrm{NFE}=$ No formal Education

*PRY ED. = Primary Education

*SEC ED. = Secondary Education

*TER ED. $=$ Tertiary Education

Table 5 shows the overall $\chi^{2}$ calculated value with its corresponding $\mathrm{P}-$ value for perception of harmful traditional practices among women of childbearing age based on their level of education $\left(\chi^{2}=73.289, \mathrm{P}=.001\right)$. Since the overall $\mathrm{P}$-value $(\mathrm{P}=.001)$ is less than .05 level of significance ( $\mathrm{P}$ $=.001<.05)$, the null hypotheses of no significant difference in the perception of harmful traditional practices among women based on level of education was, therefore, accepted. This implies that the perception of harmful traditional practices among women was not dependent on level of education.

\section{Summary of Results}

The results showed that 49.3 per cent of women of childbearing age perceived highlighted traditional practices to be harmful to women (Table 1). Women in age groups 3946 years $(56 \%)$ and $31-38$ years $(52.8 \%)$, more than women in age groups $15-22$ years $(51.3 \%)$ and $23-30$ years $(50 \%)$ respectively perceived traditional practices to be harmful to women (Table 2). Furthermore, results showed that 62.5 per cent of women with no formal education-NFE, 57.6 per cent of women with secondary education, 52.7 per cent of women with primary education and 33.1 per cent of women with tertiary education perceived that traditional practices are harmful to women (Table 3$)$. A significant difference $\left(\chi^{2}=\right.$ $12.01, \mathrm{P}=.193>.05)$ was found in the perception of harmful traditional practices among women based on their age (Table 4 ) while no significant difference $\left(\chi^{2}=73.289, \mathrm{P}=.001<.05\right)$ was found in the perception of harmful traditional practices among women based on level of education (Table 5).

\section{Discussion}

The study findings indicated that low proportion of women perceived the highlighted traditional practices as harmful to women. This result shows that substantial proportion of women did not perceive HTPs as harmful to women because they are viewed as integral parts of the culture where they exist. Also, women are compelled to observe these practices by the traditional custodians of cultural norms and beliefs (community leaders). This perpetual subjugation of women to observance of cultural practices enhances preservation of cultural practices and beliefs without taken cognizance of the fact that HTPs are either beneficial or detrimental to women's health. This finding is consistent with the finding of other study, which confirmed that cultural beliefs impact women's lives as they affect their share of power and decision making in the household and at the community and national level. These beliefs also affect women's access to and participation in employment, education, health care, land and property ownership, credit and shelter and other aspects of the African socio economic structure (21).

The finding is also consistent with the finding of a study conducted in Nigeria which found that adolescent boys and some adolescent girls hold attitudes that condone forced sex in a variety of situations. For example, in different samples of adolescents, $80-98 \%$ of girls and boys felt that forced sex was condoned if a man paid a bride price for a woman, or if he has spent a lot of money on her (37-74\%). Girls are less likely to hold these attitudes than boys but a significant percentage of girls also reported these attitudes. Many respondents blamed the female victim for inviting the forced incident (60-75\% of males and $40-50 \%$ percent of females). Many respondents voiced the view that rape was a weapon of punishment to teach an unwilling female. Findings from the Nigerian study confirmed that many rape victims suffer in silence, not even telling their parents. They reported feelings of shame and fear that they would be blamed or stigmatized for provoking the incident. These norms are deeply rooted in Nigerian cultures, and their origin may be traced to the generally low socio-economic status of women in the country. However, violence based on these norms only serves to perpetuate this low status (22).

With respect to the variables examined in this study, age and educational level of women, age of women significantly influenced perception of HTPs while level of education had no significant impact on women's perception of HTPs. These results are in consonance with the findings of other studies in developing countries $(23,24,25)$. Educational attainment, occupation and household wealth are markers of economic resources which empower women to take control of their own health and facilitate easy access to quality maternal health care.

This finding suggests the need for programmes to improve women's status and autonomy, and also involve women's 
partners in maternal health programmes so as to educate them on cultural practices that are inimical to girl-child and women's health.

Study findings should be interpreted in view of some limitations. First, the study used primary sampling units as a proxy for the community. The women were selected from primary health centres in Oru LGA, Imo State. Thus, women who were not registered at the PHCs could not participate in the study. This may impinge selection bias effect on the study.

Second, some important factors known to influence women's perception of critical public health issues (e.g., religion, socio-economic status, occupation) were not included in our analyses due to data limitation. The exclusion of these vital variables may have biased the estimates of the measured variables in this study. Third, the community variables were constructed by aggregating the individual level characteristics at the community level and this may be associated with problem of making inferences at a higher level based on information from data collected at the individual level (26). Lastly, the descriptive nature of the survey does not allow for cause-effect inferences. However, the study remains significant.

Also, qualitative research is required to adequately understand the association between the incidence or perpetration of HTPs and individual and community factors that promote occurrence of HTPs.

\section{Conclusion}

The results indicated that small proportion of women perceived the listed HTPs as harmful to women and girls. This implies that HTPs are prevalent in the community and that many women are still experiencing them. Cultural and personal factors are significantly associated with women's perception of HTPs.

\section{Recommendations}

Community health care workers (CHEWs) at the rural areas should formulate and share strategies with other professionals in allied health fields to address the priority HTPs at the community level with focus on community and women's leaders because interventions conceived and implemented without consideration for community context are likely to have limited or no impact. Also, nongovernmental organizations and national civil society, supported by three tier of government in Nigeria should develop robust, rather than anecdotal advocacy and evidence to contribute to shadow reporting on national progress in addressing HTPs. To eradicate the vicious circle of poverty that holds women in bondage over decades, national and community specific interventions that allow equitable distribution of wealth, employment/economic opportunities and provision of maternal health services should be implemented. Significantly, there is need for programmes that explore the best approaches to elevate women's status in reference to education and socio-economic status in low resource communities.

\section{Authors' Contributions}

Dr. Samson Agbaje participated in the article writing, conception of the methodology, conducted the statistical analysis and edited the manuscript; Dr. Benedicta Agu participated in the supervision, validation of instrument, interpretation of results; Kenechukwu Osakwe participated in the article writing, formulation of questionnaire items, questionnaire administration, design of sampling procedures and retrieval of filled copies the of questionnaire from the women.

\section{Acknowledgements}

The authors would like to express sincere gratitude to registered women at the sampled PHCs in Oru-West LGA who gave their time and responses during the study, research assistants who assisted during administration of copies of questionnaire, nurses and matrons at the sampled PHCs for their immense assistance and contributions.

\section{References}

[1] United Nations International Children's Fund (2012). Protecting children from harmful practices in plural legal systems. Office of the Special Representative of the Secretary on Violence against Children. New York: United Nations.

[2] African Centre for Women. Occasional Paper No.1. Traditional and Cultural Practices Harmful to the Girl-Child: A Cross Sectional Review. Economic Commission for Africa, 1997. Print.

[3] African Union Commission. (2012). Harmful traditional practices towards women and girls in Africa. A Report to Make a Difference for the Future of all Girls and Women. African Union Commission: Department of Social Affairs. http://acts-

consultancy.com/docs/HTP\%20REPORT\%20REAL\%20FIN AL\%20.pdf

[4] Accessed 29 December, 2014

[5] Oyekanmi F. Ed. Men, Women and Violence. Dakar: Council for the Development of Social Science Research in Africa, 2000

[6] Marchie C L, Anyanwu F C. Relative contributions of sociocultural variables to the prediction of maternal mortality in Edo South Senatorial District, Nigeria. African Journal of Productive Health, 2009;13: 2

[7] Kouyate M. Harmful traditional practices against women and legislation. Expert group meeting on good practices in legislation to address harmful practices against women at United Nations Conference Centre. Addis Ababa, Ethiopia: United Nations, 2009.

[8] Igberase, G. Harmful cultural practices and reproductive health in Nigeria.

[9] Continental Journal of Tropical Medicine, 2012;6(1): 27 
[10] Smith J, Jones WK, Keike BJ, Wilcox A. Female genital mutilation and female circumcision. Who is at risk in the USA? Centre for Disease Control and Prevention: Atlanta.(2000)

[11] American Academy of Pediatrics (1998).Female genital mutilation.

[12] Pediatrics, 102 (1): 153-156

[13] UNICEF. Female Genital Mutilation/Cutting: a statistical overview and exploration of the dynamics of change. UNICEF: New York. 2013.

[14] Lindsay P, Norman DA. Human information processing: An Introduction to Psychology, 1977.

[15] Pomerantz JR. Perception: An overview. In L. Nadel (ed.), Encyclopedia of Cognitive Science, 3. 2003. London: Nature Publishing Group. pp. 527-537.

[16] Smith ER, Mackie DM. Social Psychology-2nd edition. 2000. Psychology Press. pp. 20.

[17] Delamate JD, Michener HA, Myers, DJ. Social Psychology5th edition. 2003. Wadsworth Publishing.

[18] Dunning D. What is the word on self-motives and social perception: Introduction to special issue. Motivation and Emotion, 2001, March;25 (1): 1-6

[19] 1995 United Nations. Programme of action. Adopted at the International Conference on Population and Development, Cairo, 5-13 September 1994. New York: United Nations. http://www.unfpa.org/public/site/global/publications/pid/1973

[20] World Health Organization. Defining sexual health. Report of a technical consultation on sexual health 28-31 January, 2002 Geneva. Geneva: WHO.2006.

[21] United Nations International Children's Fund. Early marriage a harmful traditional practice a statistical exploration. ISBN: 92-806-3869-6.UNICEF: New York. 2005.
[22] Ras-Work B. The impact of harmful traditional practices on the girl child. Expert Group Meeting, Elimination of all forms of discrimination and violence against the girl child. UNICEF Innocenti Research Centre Florence, Italy.2006

[23] Onyekuru BU. Obnoxious cultural practices associated with bereavement among people of the South East geopolitical zone of Nigeria. Journal of Emerging Trends in Educational Research and Policy Studies, 2011; 2 (5): 357

[24] AbaneH. "Towards Research into Wife Battering in Ghana: Some methodological issues." Men, Women and Violence. Ed. Oyekanmi, F. Ed.Dakar: Council for the Development of Social Science Research in Africa, 2000. Print.

[25] Ajuwon A. "Attitudes. Norms and experiences of sexual coercion among young people in Ibadan, Nigeria.”Jejeebhoy, S, Shah. I, and Thapa, S. Eds. Sex

[26] Without Consent: Young People in Developing Countries. London: Zed Books, 2005. Print. p.102

[27] United Nations Population Fund (UNFPA). Sub-Saharan Africa's maternal death rate down 41 percent.201 http://africa.unfpa.org/

public/cache/offence/news/pid/10767.Accessed 29 December, 2014.

[28] Islam MR, Odland JO. Determinants of antenatal and postnatal care visits among indigenous people in Bangladesh: a study of the Mru community. Rural Remote Health. 2011; 11(2):1672.

[29] DhaherEnas, Mikolajczyk RT, Maxwell AE et al. Factors associated with lack of postnatal care among Palestinian women: A cross-sectional study of three clinics in the West Bank. BMC Preg and Childbirth.2008; 8: 26.

[30] Boco AG. Individual and community level effects on child mortality: An analysis of 28 Demographic and Health Surveys in sub-Saharan Africa. DHS Working Papers. 2010: Calverton, Maryland, USA. 